\title{
The Influence of Social Interaction Learning Model, Learning Motivation, Social Attitude on the Student Learning Result of Geographic Subject in Public Senior High Schools in Aceh Province
}

\author{
Tengku Muhammad Sahudra ${ }^{1}$, Murniati $^{1}$, Deny Setiawan ${ }^{1} \&$ Alamsyah Taher ${ }^{1}$ \\ ${ }^{1}$ University of Syiah Kuala, Indonesia \\ Correspondence: Tengku Muhammad Sahudra, University of Syiah Kuala, Indonesia. E-mail: \\ syaeri.unri.jp@gmail.com
}

Received: September 6, 2019

Accepted: September 26, 2019

Online Published: September 29, 2019

doi:10.5539/ep.v8n2p41

URL: https://doi.org/10.5539/ep.v8n2p41

\begin{abstract}
Purpose - The aim of this research is to test the difference of sudents learning outcome of Geographic subject taught with social inquiry learning model, social simulation and students' social investigation, social behavior, learning motivation of SMA in Aceh Province.

Design/methodology/approach - The research methodology employed in his research was quasi-experimental with the design using a Non-equivalent Control Group Design method. The experimental class and the control of this research are selected randomly. The subject of this research is ninth grade student of public SMA in Aceh Province, Indonesia. Based on the early observation that the researcher conducts, total public SMA in Aceh is 344 schools. This study took 3 (three) study group of every SMA to be managed as a research subject, which was a class taught using a group investigation, social inquiry, and social simulation learning method. Data analysis technique is inferential analysis intended to test the research hypothesis conducted by using varians analysis technique (ANAVA).

Findings - The findings that there are no differences in student learning outcomes of Geography subject taught with social inquiry learning models $\left(\mathrm{A}_{1}\right)$, social simulation learning models $\left(\mathrm{A}_{2}\right)$ and group investigative learning models $\left(\mathrm{A}_{3}\right)$. There are differences in the learning outcome of geography subject and different social attitude, which is a high social attitude $\left(B_{1}\right)$ and social attitude $\left(B_{2}\right)$. There is an interaction between the learning model (A), social attitudes (B) and learning motivation (C). There is an interaction between learning models (A) and social attitudes (B). There is an interaction between learning model (A) and learning motivation (C). There is an interaction between learning model (A) and learning motivation (C).

Originality/value - The research on the application of social interaction learning model to improve learning motivation, social attitude, and students learning outcome at the geographic subject of SMA in Aceh Province, Indonesia.
\end{abstract}

Keywords: social, learning model, learning motivation, geographic subject

\section{Introduction}

Education plays a role to prepare a human resource for a development purpose. The pace of action of development is always tried to be in rhythm with the demands of the time. Current development always raises new challenges which are partially unpredictable beforehand.An educational system is an inseparable part of socio-culture life and society as a suprasystem. The educational system development has no meaning at all if not synchronous with national development. A closed link between educational field as a system and socio-culture system, as a suprasystem in which the educational system becomes its part, creates a condition in a way that intern problem of the education becomes much more complex.

Law Number 20 of 2003 on national education system stipulates that national education functions develop the ability and builds characteristic as a dignified country civilization in order to educate the life of the nation. Education aims to develop the potential of those receiving education to become a man who has faith and devotion to the Almighty God, noble, is healthy, knowledgeable, competent, creative, independent and to become citizens who are democratic and responsible. 
Every country needs a quality resource because it will give a positive impact on the development of a nation in various fields, not only in the mastery of science and technology expected but also a good mental attitude. For that matter, every country always improves the quality of human resources it has. This can be done by improving the quality of national education because it will create quality human resources too and finally will support the improvement of national development.

Education is a discussion and a systematical influence of someone's maturity through instruction, regulation and a balanced improvement, the whole ability of human's life, physical, social, intellectual, art and spiritual based on the level of their essential for they themselves and socio-community that directs into education.

In this current globalization era, competition among human resources are so high and still added with various industries competing to produce a satisfied product. One of the ways conducted by the government to prepare students to be ready to enter the working world and to compete in the globalization era is through an education at Senior High School (SMA) which causes them to develop a potential owned by society for the development of nation and country.

High school education is expected to improve students' ability to develop themselves in accordance with the development of science, technology, and art, as well as prepare the students to enter into the working world and develop professionalism attitude. High School education is a form of high school units established to continue and widen primary school education and prepare students to enter into the working field and develop professionalism attitude. High school education is one of the educational institutions which is responsible to create human resources having competence, ability, and skill so the graduates can continue their study to a higher level.

One effort to improve the quality of the educational institution is through the improvement of teacher's performance. The quality of an educational institution is truly influenced by an input for the educational system, among others, students, teachers, and supporting facilities for the teaching process. Those three factors depend on and influence each other in creating the success of the teaching process.

A teacher is someone who based on his/her education and skill appointed by the implementor of a university with teaching as the main task. According to Law Number 15 of 2005 on Teacher and Lecturer, a teacher is a professional educator of a scientist with the main task of transforming, developing and disseminating science, technology, and art through education, research, and outreach program. The main factor that causes the low quality of education is the teacher condition, which is the qualification is not feasible or not linear to the mainstream.

The teaching process is a process that contains a series of teacher and students' act of the reciprocal relationship happening in the educative situation to achieve a goal. Teaching is a process of interaction between students and teacher as well as working source at a working field. Teacher's ability to teach is the major dimension to conduct monitoring. This assessment can be done by the teachers, headmaster or students through their perception. Performance is a level of teacher's success in finishing his/her job. A factor determining teacher's working level (working achievement) is, among others, working assessment. Performance assessment relates to how good someone performs his/her job signed to him. Formal performance assessment happens in a certain period like once or twice a year. Performance assessment is an activity conducted by a management/supervisor to assess worker performance by comparing performance with explanation/description in a certain period.

Teacher as an educator is expected to not dominate learning activity, but to help to create a conducive situation and give motivation and guidance, hence the students can develop the potential and creativity through a learning activity. Determining the method or learning activity is one of the important steps which can support the achievement of the learning goal. For that matter, the teacher should apply the variation of learning method and emphasize that the students must be active during the learning activity so the teacher acts as an enabler and motivator.

Teaching-learning is an activity with educative value. Educative value colors the interaction between teacher and student. Educative interaction appears from the teaching-learning activity conducted, directed to achieve a certain goal that has been formulated before the learning activity. Teaching activity includes many things, i.e. all stuff related to human development. Starting from the physical, health, skill, mind, feeling, willingness, and social improvement or even until faith development, all of them are handled by the teacher.Therefore, teaching plays a role to create a more perfect human, make them improve their life from the natural life to being cultured.

Teaching-learning process or Proses Belajar Mengajar abbreviated as PBM emphasizes the effort so that the material of education process can be easily observed, internalized, lived out, transferred, and implemented in a real life. In order to achieve a goal, PBM never separated from the art of educating because the concepts of education are not always fit for being applying at a field. Education frequently seeks for strategy, approach, or new tactics for 
the goal achievement.

Based on Highet (1955:32), learning is considered an art because it also asks for the quality and personal characteristic. As an art, teaching involves methods like a teacher who has to love the subject and the students. For Axelrod, a teacher is like an artist because he/she is a representation of the various style. The art is not only a superficial and decorative, but also an authentic expression to be who he/she is in front of the students. Therefore, a teacher has to be able to design an innovative teaching method for the students.

The originality of this research seems on the deep observation of Social Interaction Learning Model, Learning Motivation, Social Behavior on the Student Learning Outcome of Geographic Subject.The main problem of the learning in a formal education especially Geographic subject is the lack of student's absorbtion power. This can be seen from the student's learning outcome that is still apprehensive. This matter is actually the result of learning condition which is still conventional and does not touch the students' dimension field. In a more substantial meaning, learning process until today is still dominated by the teacher and does not give access to the students to independently develop through a finding during its thinking process.

On the other sides, empirically, based on the study analysis result of the low learning outcome of the students caused by the dominance of conventional learning process. Of this learning, the class situation tends to be teacher-centered so the students are so passive. However, teachers are more likely to apply that model because it does not need a tool and practice material, just to explain the concepts existing in the textbook or another reference. By this matter, students are no more taught the learning strategy which can understand how to learn, think, and motivate themselves, even those aspects are the key of success.

The importance of a concept in a teaching-learning process truly influences behavior, decision, and the ways of breaking a problem. Hence, the most important thing is meaningful learning which is not only like pouring water in a glass. In such condition, teachers are encouraged to be competent meaning that they have to be able to formulate learning insight which is more interested in and liked by students.

The fact in a field shows that the students only memorize a concept and is less capable of using that concept if dealing with a problem in a real life connecting to the concept owned. Moreover, students are even less capable of determining the problem and formulating it. Talking about the teaching-learning process frequently make us dissapointed, even if related to the students' understanding on the teaching material.

Based on Arends (1997:53), educators always require students to study but rarely to explain to them how to study, teachers also require students to solve a problem but never taught them how to actually solve the problem. Independently try to seek for problem-solving and knowledge which relates to, produce a truly meaningful knowledge.A logic consequence because trying to seek for problem-solving independently will give a concrete experience, that experience can be also used to break a similar problem because it gives a meaning to the students.

An interesting innovation accompanying the change of paradigm in a learning process is being found and applied innovative-progressive learning models which are able o develop and dig up the students' knowledge concretely and independently. This innovation starts and is adapted from the scientist's working method in seeking new knowledge.

Based on that reason, so it is important for the educators, especially the teacher, to understand the characteristic of the material, students and the learning methodology in a learning process especially related to the selection of modern learning models. Hence, the learning process will be more versatile, innovative, and constructive in order to construct knowledge insight and its implementation so can increase motivation and the learning outcome.

Until today, learning is still dominated by an insight that knowledge is as a fact tool that has to be memorized. Teacher as a presenter, students as a receiver, and the lectures learning model still become the first option as a learning strategy so cause students to be bored and impact on the students' capability to absorb the material.

Proper usage of method will have an impact on the student's willingness to learn and seek for more information because encouraged by the need and the big interest so that expected can optimize the potential owned by each student. Such a condition make teachers will no longer become the source of learning, but will more play a role as an enabler where the students are given a chance to explore to understand the material.

The success of learning process is the main studd that is coveted in the implementation of education at school. In the learning process, the main component is teachers and students. Teacher-Centered Learning (TCL) is now still many applied in a learning process in a class by the reason of TCL is practice and does not need much more time. Students only get theoretical and abstract material while the passive students only listen to the teacher lecturing in front of the class. Because of that behavior, the students are less creative in breaking the problem, low participation, cooperation in a group is not optimal, teaching-learning activity is not efficient and finally, the learning outcome is 
not good.

Learning model development always changes from time to time. A traditional learning model is now being left and changed with the more modern model. Best hit learning model is a cooperative learning model.

This cooperative learning is intended to be able to change a teacher-centered to student-centered education. Social interaction is one of the models of cooperative learning. This model emphasizes an activity and interaction among the students to motivate each other and help to master learning material to achieve maximal learning outcome. Social interaction learning model applied at geographic learning material will help students to find and build the understanding of that main material, so this will be able to give a chance to students to be more active in building a concept of material, finding illustrations through experience in group cooperation.

Social interaction learning model group is laid on Gestalt's Field theory that emphasizes the harmonious relationship between individual and society (learning to live together). This theory is pioneered by Max Werheimer (1912:78) accompanied by Kurt Koffka and W. Kohler who have an opinion that object or a certain experience will be considered as a whole organized. Hence, the implication of this theory is that the learning will be more meaningful if the material is given completely.

This model also based on the thinking that cooperation is one of the phenomenon of community life which is very important. This model group emphasizes the individual relationship with other people or society. This group centers on the process where reality is offered socially. As the consequence, social-oriented models above prioritize to improve individual skill to connect to others, to act in a democratic process, and to work productively in the society.

Even though this model emphasizes more on the social relationship than on the other aspects, the figures in this group also emphasize the development of study awareness that is academic in nature. Learning models categorized in this group is a learning model of Group investigation, Social Inquiry, Playing a Role, and Social Simulation.

By applying an innovative learning model is expected to increase motivation. Motivation is the most important factor in improving learning achievement. High motivation in learning will result in a good learning outcome, based on Sardiman (2003:90), motivation is a non-intellectual physical factor. The unique role is in order to grow the desire of the student to feel ok and have a spirit to study.

Another important factor that influences geographic learning outcome except motivation is an attitude. Based on D. Krech and RS. Crutchfield quoted by Ahmadi (2007:96), attitude is a fixed organization from the process of motivation, perception or observation of an aspect from an individual's life. This opinion emphasizes the relationship between attitude and motivation or perception. This is a two-way relationship or influencing each other. An attitude can be influenced by someone's motivation and perception on an object or a certain condition or in contrary someone's perception and motivation is influenced by someone's attitude on an object and a certain condition.

The average value for National Exam of social science majors in Aceh Province over the 5 years is still under the standard of 6 (six) subjects that should be tested, i.e. Indonesian language, English language, mathematics, economics, Sociology, and Geography.

Data of school year 2007/2008 presented that the average value of UN in Aceh province was 6.02. While nationally, it was about 7.08. In school year 2008/2009, the average value of UN in Aceh province was 6.74. The national average value was about 7.05. In school year 2009/2010, the average value for UN in Aceh Province was 7.12. The national average value was 7.18. In school year 2010/2011, the average value for UN in Aceh province was 7.65. In school year 2011/2012, the average value for UN in Aceh province was 7.53, while the national average value was 7.45. In school year 2012/2013, the average value for UN in Aceh Province was 5.49. The national average value for UN was 6.07. meanwhil, in academic year 2013/2015, the national average value was 5.86. Meanwhile, UN average value in Aceh Province was 5.18.

The data show that generally, over the 7 years, the average value of UN for social students in Aceh province is increasing, but still under the national standard. Based on the earlier observation at several SMA in Aceh, geographic learning conducted by teachers still uses lecturers' teaching styles and does not use an interesting media. The teacher does not realize that the conventional learning method they use is monotonous and boring so that the students have less enthusiasm, tend to be passive, and lack interest in a teaching-learning activity so they have no interest to study. This becomes one of the causes of the student's learning outcome which tends to be low. For that matter, the researcher is interested to focus the research on the application of social interaction learning model to improve learning motivation, social attitude, and students learning outcome at the geographic subject.

Based on the problem statemen above, it can be explained that the aim of this research is to test the difference of 
sudents learning outcome of Geographic subject taught with social inquiry learning model, social simulation and students' social investigation, social behavior, learning motivation of SMA in Aceh Province.

\section{Literatur Review}

This conceptual framework needs to explain theoretically between independent and dependent variable. Research concepual framework is a short illustratio of the relationship of a concep with another concept whill will be observed ot illustrate the influence or relationship among an accudent (anoher phenomenon). A teacher is the main factor that influences the educational system. A teacher plays an important role in a whole process of education, where teaching is guiding a sudents' activity. In a teaching-learning process, a teacher has to be able to design an innovative learning model so that the students have an interest in studying.

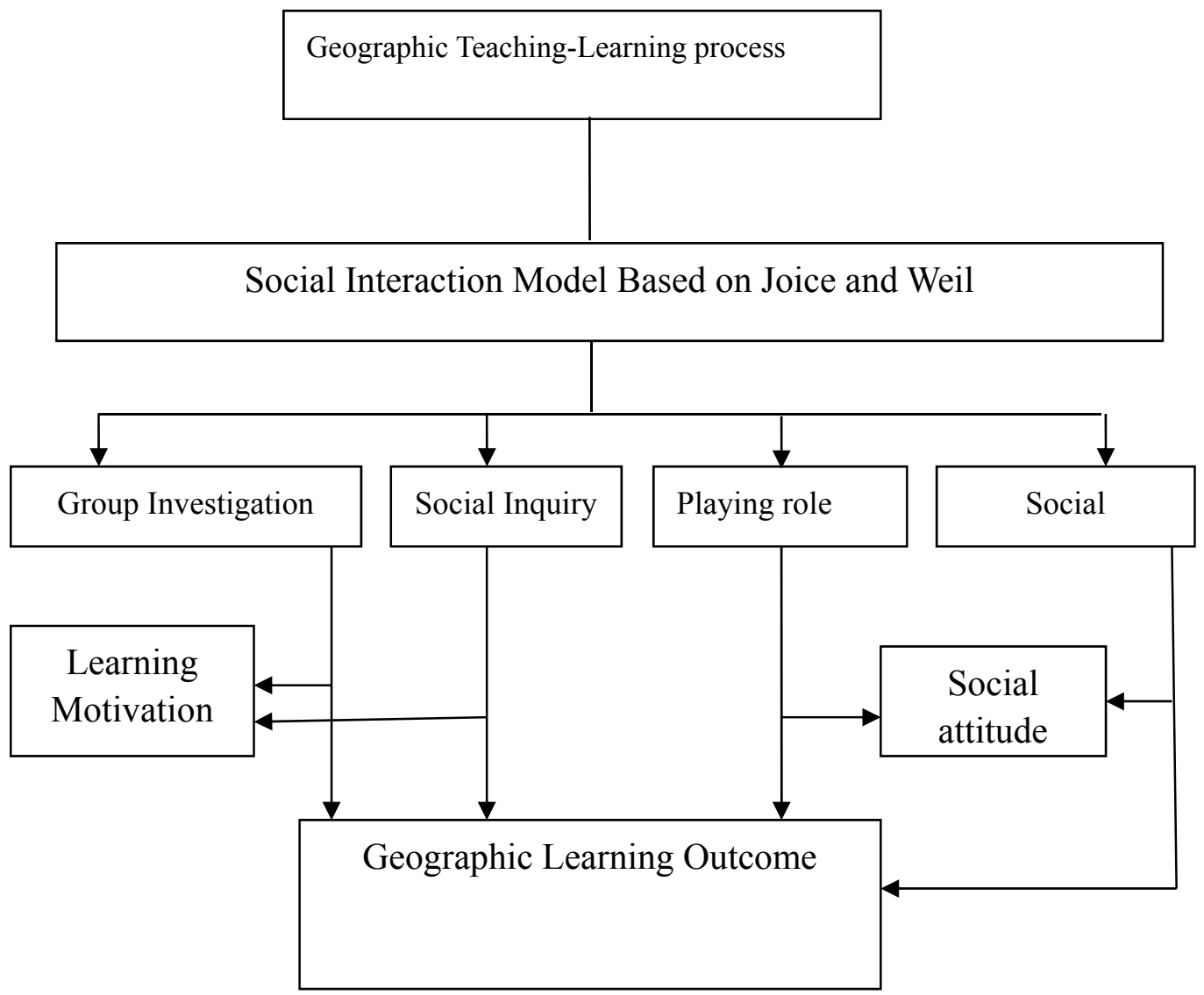

Figure 1. Conceptual framework

This conceptual framework needs to explain theoretically between independent and dependent variable. Research conceptual framework is a short illustration of the relationship of a concept with another one which will be observed or illustrate the influence or relationship among an accident (anoher phenomenon).

A teacher is the main factor that influences the educational system. A teacher plays an important role in the whole process of education, where teaching is guiding a students' activity. In a teaching-learning process, a teacher has to be able to design an innovative learning model so that the students have an interest in studying.

Learning design is a procedure consisting of steps, in which those steps consisted of analysis, designing, developing, applying and assessing the learning outcome (Seels and Richey, 1994:33). That result is also proposed by Seels and Glasgow (1998:1) that the learning design is a process of learning problem solving conducted by systematical analysis on learning condition.

In order to determine learning design and subject which will be delivered, it needs to know that what designer actually conducts is to create a conducive learning situation so that the learning goal can be achieved and the students feel comfortable and motivated during the learning process. Before and after learning, the students can be influenced by various factors both physical and mental, such as fatigue, sleepy, bored, and surfeited. Students' learning moivation is truly needed in an education world. When students have craved for studying, the teacher will 
be very easy to train the student.

To be not monotonous, a teacher has to be able to choose a student-centered education, like social interaction learning model. In a teaching-learning process, that kind of model not only make students active but also teach how students can socialize to their friends. This is called as building social attitude to the students. Once students' learning motivation and social behavior have been good so their learning outcome will be good too. This is what actually expect from the teaching-learning process.

Several relevant studies are as follows.First, the finding of Aleksandra Šević from University of East Sarajevo Faculty of Philosophy Pale Republic of Srpska, Bosnia and Herzegovina in 2015 entitled PROBLEM BEHAVIOUR AT EARLY AGE - BASIS FOR PREDICTION OF ASOCIAL BEHAVIOUR, proposes that there are many students having bad social attitude like stealing, lying, smoking, drinking and gambling, being bored at school, going to school without books and being late. That attitude appears because of the lack of family and teacher's care and having no self-motivation.

Second, The research result of Stanislava Olić, dr Jasna Adamov, dr Snežana Babić-Kekez Faculty of Sciences entitled MOTIVATION AS A PREDICTOR OF PUPIL'S ACHIEVEMENT IN CHEMISTRY investigates that there is a positive and significant correlation between learning outcome and student motivation. The fact shows that students with high motivation in learning also have higher achievement.

Third, the research result of MT Simonida Plisnić from University of Pittsburg entitled Supporting Social Interaction in an Intellegent Collaborative Learning System said that The results suggest that structured, high-level knowledge of student conversation in context may be sufficient for automating the assessment of group interaction, furthering the possibility of an intellegent collaborative learning system that can support and enhance the group of learning process.

Fourt, the research result of Ni Md.Liana Armita Sari, Dsk.Pt.Parmiti, I Nyn.Murda entitled THE INFLUENCE OF INTERACTION SOCIAL LEARNING MODEL ON THE SIX GRADE STUDENTS LEARNING OUTCOME SOCIAL LEARNING OUTCOME OF SOCIAL SUBJECT AT SD GUGUS 1 KECAMATAN

TABANAN. The finding shows that there is a significant difference in social subject learning outcome between students taught using social interaction learning model and the conventional learning model. Its analysis result shows that $\mathrm{t}$ count is 2.85 and $\mathrm{t}$ table is 2.021 for $\mathrm{db}=\mathrm{n} 1+\mathrm{n} 2-2=48$ with significance level of $5 \%$. This indicates that the learning outcome of a student taught using social interaction model is better than to use a conventional learning model.

The hypothesis proposed by this researcg is as follows:

1) There is a difference of geographic learning outcome between the students taight using social inquiry, social simulation, and group investigation learning model.

2) There is a difference of Geographic learning outcome of a student with a different social attitude.

3) There is a difference in learning outcome by using different learning motivation.

4) There is an interaction between learning model, social attitude and learning motivation.

5) There is an interaction between learning model and social attitude.

6) There is an interaction between learning model and learning motivation.

7) There is an interaction between social behavior and learning motivation.

\section{Methodology}

The research methodology employed in his research was quasi-experimental with the design using a Non-equivalent Control Group Design method. This experimental form is used to deal with the difficulty in determining control group in the research, Sugiyono (2010:114-116). This Non-equivalent Control Group Design method gives pre-test in advance without selecting randomly either a control group or experimental group so that the treatment result can be said more accurate. The experimental class and the control of this research are selected randomly.

The experimental class and the control of this research are selected randomly. Research design used to conduct this research is factorial $4 \times 2 \times 2$ as in table 1 below: 
Table 1. Research design

\begin{tabular}{ccccccc}
\hline \multirow{2}{*}{ Factor C } & \multicolumn{7}{c}{ Factor A/B } \\
\cline { 2 - 7 } & \multicolumn{2}{c}{$\mathrm{A}_{1}$} & \multicolumn{2}{c}{$\mathrm{A}_{2}$} & \multicolumn{3}{c}{$\mathrm{A}_{3}$} \\
\cline { 2 - 7 } & $\mathrm{B}_{1}$ & $\mathrm{~B}_{2}$ & $\mathrm{~B}_{1}$ & $\mathrm{~B}_{2}$ & $\mathrm{~B}_{1}$ & $\mathrm{~B}_{2}$ \\
\hline $\mathrm{C}_{1}$ & $\mathrm{~A}_{1} \mathrm{~B}_{1} \mathrm{C}_{1}$ & $\mathrm{~A}_{1} \mathrm{~B}_{2} \mathrm{C}_{1}$ & $\mathrm{~A}_{2} \mathrm{~B}_{1} \mathrm{C}_{1}$ & $\mathrm{~A}_{2} \mathrm{~B}_{2} \mathrm{C}_{1}$ & $\mathrm{~A}_{3} \mathrm{~B}_{1} \mathrm{C}_{1}$ & $\mathrm{~A}_{3} \mathrm{~B}_{2} \mathrm{C}_{1}$ \\
$\mathrm{C}_{2}$ & $\mathrm{~A}_{1} \mathrm{~B}_{1} \mathrm{C}_{2}$ & $\mathrm{~A}_{1} \mathrm{~B}_{2} \mathrm{C}_{2}$ & $\mathrm{~A}_{2} \mathrm{~B}_{1} \mathrm{C}_{2}$ & $\mathrm{~A}_{2} \mathrm{~B}_{2} \mathrm{C}_{2}$ & $\mathrm{~A}_{3} \mathrm{~B}_{1} \mathrm{C}_{2}$ & $\mathrm{~A}_{3} \mathrm{~B}_{2} \mathrm{C}_{2}$ \\
\hline
\end{tabular}

Description

A $=$ Social Interaction Learning Model

$\mathrm{B}=$ Social behavior

$\mathrm{C}=$ Learning Motivation

$\mathrm{A}_{1}=$ Social inquiry learning model

$\mathrm{A}_{2}=$ Social simulation learning model

$\mathrm{A}_{3}=$ Group investigation learning model

$\mathrm{B}_{1}=$ High social attitude

$\mathrm{B}_{2}=$ Low Social attittude

$\mathrm{C}_{1}=$ High learning motivation

$\mathrm{C}_{2}=$ Low learning motivation

That experimental design selection is based on the consideration that the design relies on several factors which influence internal validity. Internal validity refers to the definition of whether the experimental result really acts as a cause of treatment and is not caused by other factors influence. Other than internal validity, external validity is also needed to be paid attention Based on Mason and Bramble, external validity refers to the definition to what extent the research result can be generalized.

The subject of this research is ninth grade student of public SMA in Ache Province. Based on the early observation that the researcher conducts, total public SMA in Aceh is 344 schools. For the eastern part of Aceh, the study was conducted at SMAN 1 Langsa, for the Northern part of Aceh was at SMAN 1 Lhoksumawe, for the central part of Aceh was at SMAN 8, for the western part of Aceh was at SMAN 1 Calang, for the southern part was at SMAN 1 Tapak, for the south end of Aceh was at SMAN 1 Gunung Meriah, for the southeast part of Aceh was at SMAN 1 Kotacane, and in Aceh Capital, the study was conducted at SMAN 4 Banda Aceh. This study took 3 (three) study group of every SMA to be managed as a research subject, which was a class taught using a group investigation, social inquiry, and social simulation learning method.

Data analysis technique is inferential analysis intended to test the research hypothesis conducted by using varians analysis technique (ANAVA). In order to give a clear limitation for the research variables so it is presented the definition of each operational below.

First, Social Interaction Mearning Media. 1) Social Inquiry. A social inquiry is a learning strategy from a social group (social family) of sub-group of society concept. This sub-group is based on the assumption that educational method aims at developing an ideal community member which can live and maximize the quality of community life. For that matter, students must be given a proper experience of how the way they solve the problems in society. Through that experience, every individual will be able to build a meaningful knowledge for themselves and society. 2) Social Simulation. Simulation derives from the word stimulate meaning pretending or acting as if. The word stimulant means mock or fake action. Hence, simulation and learning method are intended as a method to explain something (learning material) through a pretending behavior or imitation behavioral process as if in a real condition. 3) Group Investigation. Group Investigation is a funding learning conducted in a group: students form a group to conduct an observation that enables them to find fact and principle.

Second, Social Attitude. Students' social attitude is a process of students' personality development as a member of society to connect to other people. Social development is a process of social-self formation (personal in a society), which is individual in the family, culture, nation, etc.

Third. Learning Motivation. Learning motivation is an internal condition which is able to bring out an 
encouragement to study to achieve a goal in order to fulfill needs. Fourth, Learning Outcome. Learning outcome of this research is the level of students' cognitive mastery (knowledge) after receiving teaching-learning process at school, stated in the form of score received from the test result of a number of geographic learning materials. The learning outcome is limited to geographic subject for students in 11 th grade.

\section{Result and Discussion}

Hypothesis testing of the first, second, and third research is conducted by using three-way variance analysis. The data used to conduct this hypothesis testing is as in table below:

Table 2. Three-way ANAVA statistic

\begin{tabular}{|c|c|c|c|c|c|}
\hline \multirow{2}{*}{ Factor A } & \multirow{2}{*}{ Factor B } & & \multicolumn{2}{|l|}{ Factor $\mathrm{C}$} & \multirow{2}{*}{$\begin{array}{l}\text { Total } \\
\text { Row }\end{array}$} \\
\hline & & & $\mathrm{C}_{1}$ & $\mathrm{C}_{2}$ & \\
\hline \multirow{8}{*}{$\mathbf{A}_{1}$} & \multirow{4}{*}{$\mathbf{B}_{1}$} & $\mathrm{n}$ & 40 & 41 & 81 \\
\hline & & $\sum \mathrm{X}$ & 2950 & 2124.5 & 5074.5 \\
\hline & & $\sum \mathrm{X}^{2}$ & 221212 & 116490.30 & 337702.30 \\
\hline & & $\bar{X}$ & 73.75 & 51.82 & 62.65 \\
\hline & \multirow{4}{*}{$\mathbf{B}_{2}$} & $\mathrm{n}$ & 43 & 36 & 79 \\
\hline & & $\sum \mathrm{X}$ & 2582.5 & 1922 & 4504.5 \\
\hline & & $\sum X^{2}$ & 160910.80 & 111169 & 272079.80 \\
\hline & & $\bar{X}$ & 60.06 & 53.39 & 57.02 \\
\hline \multirow{8}{*}{$\mathbf{A}_{2}$} & \multirow{4}{*}{$\mathbf{B}_{1}$} & $\mathrm{n}$ & 33 & 43 & 76 \\
\hline & & $\sum \mathrm{X}$ & 2238 & 2134 & 4372 \\
\hline & & $\sum X^{2}$ & 155314 & 116014 & 271328 \\
\hline & & $\bar{X}$ & 67.82 & 49.63 & 57.53 \\
\hline & \multirow{4}{*}{$\mathbf{B}_{2}$} & $\mathrm{n}$ & 35 & 49 & 84 \\
\hline & & $\sum X$ & 2038 & 2734 & 4772 \\
\hline & & $\sum \mathrm{X}^{2}$ & 124724 & 168184 & 292908 \\
\hline & & $\bar{X}$ & 58,23 & 55,80 & 56,81 \\
\hline \multirow{8}{*}{$\mathbf{A}_{3}$} & \multirow{4}{*}{$\mathbf{B}_{1}$} & $\mathrm{n}$ & 36 & 42 & 78 \\
\hline & & $\sum \mathrm{X}$ & 2322 & 2337 & 4659 \\
\hline & & $\sum X^{2}$ & 155577 & 141387 & 296964 \\
\hline & & $\bar{X}$ & 64.50 & 55.64 & 59.73 \\
\hline & \multirow{4}{*}{$\mathbf{B}_{2}$} & $\mathrm{n}$ & 43 & 39 & 82 \\
\hline & & $\sum X$ & 2488 & 2409 & 4897 \\
\hline & & $\sum \mathrm{X}^{2}$ & 155926 & 157899 & 313825 \\
\hline & & $\bar{X}$ & 57.86 & 61.77 & 59.72 \\
\hline \multirow{4}{*}{\multicolumn{2}{|c|}{ Total Kolom }} & $\mathrm{n}$ & 230 & 250 & 480 \\
\hline & & $\sum \mathrm{X}$ & 14618,5 & 13660,5 & 28279 \\
\hline & & $\sum X^{2}$ & 973663,80 & 811143,30 & 1784807.10 \\
\hline & & $\bar{X}$ & 63.55 & 54.64 & 58.91 \\
\hline
\end{tabular}


Table 3. The summary result of Three-way Anava calculation

\begin{tabular}{llllll}
\hline Source of Variation & $\mathrm{db}$ & $\mathrm{JK}$ & $\mathrm{RJK}$ & Fh & $\begin{array}{c}\text { Ftable } \\
(\alpha=0.05)\end{array}$ \\
\hline Factor A & 2 & 748.96 & 374.48 & 1.93 & 3.02 \\
Factor B & 1 & 2572.69 & 2572.69 & 13.26 & 3.86 \\
Factor C & 1 & 9524.33 & 9524.33 & 49.09 & 3.86 \\
Interaction AB & 2 & 1715.11 & 857.33 & 4.42 & 3.02 \\
Interaction AC & 2 & 2518.56 & 1259.28 & 6.49 & 3.02 \\
Interaction BC & 1 & 4676.36 & 4676.36 & 24.11 & 3.86 \\
Interaction ABC & 2 & 6216.24 & 3108.12 & 16.02 & 3.02 \\
All groups & 11 & 27972.26 & 2542.93 & 231.17 & 1.81 \\
Internal group & 468 & 90789.34 & 193.99 & - & - \\
Total reduced & 479 & 118761.60 & & - & - \\
\hline
\end{tabular}

\subsection{The Difference of Geographic Learning Outcome Taught by the Learning Model of Social Inquiry, Social Simulation and Group Investigation}

Based on the calculation of 3-way anava as seen in table 3, source of A variation shows that the value of $\mathrm{F}_{\text {count }}=$ 1.93, while the value of $\mathrm{T}_{\text {table }}=3.02$ for $\mathrm{dk}$ (2.468) and significance level $=0.05$. For that matter, the conclusion is that there is a difference in Geographic learning outcome taught by applying social inquiry learning model $\left(A_{1}\right)$, social simulation learning model $\left(A_{2}\right)$, and group investigation learning model $\left(A_{3}\right)$. The average value of Geographic learning outcome shows insignificant difference among those three models, in which the average value of geographic learning outcome taught by applying social inquiry learning model is 59.50 , the average value of geographic learning model taught by using social simulation learning model is 57.20 and the average value of geographic learning model taught by using group investigation learning model is 59.40 .

The matter above is understandable that the learning model of social inquiry, social simulation, and a social investigation is similar to the social interaction learning model as explained by Joyce and Weil (1992). According to the research conducted by Joyce and Weil (1992) to the students in $11^{\text {th }}$ grade of a social department in Los Angels USA, the application of social interaction learning model significantly can increase the ability of students' problem-solving.

However, if traced further related to the research result conducted by several previous studies related to the application of social interaction learning models by comparing it to other learning models, hence the results of the study show that social interaction learning models provide significant differences in learning outcomes, this can be seen from a number of research results contained in various journals, among others are the research conducted by Ni Md. Liana Armita Sari, Dsk.Pt. Parmiti, I Nyn., where the results of his research show that there are significant differences in social studies learning outcomes of students who are taught using social interaction learning models with students taught using conventional learning. The results of the analysis show that $\mathrm{t}_{\text {count }}=2.85$ and $\mathrm{t}_{\text {table }}=2.021$ for $\mathrm{db}=\mathrm{n} 1+\mathrm{n} 2-2=48$ with a significance level of $5 \%$. This indicates that the students learning taught using social interaction model are better than that of a conventional learning model.

The results of the Naijan's (2014) study showed that: there are significant differences in learning outcomes between students who received an education using cooperative learning method \& conventional methods, (2) there are an interaction influences between the use of learning methods and students' social attitudes towards students' historical learning outcomes, and (3) there are significant differences in historical learning outcomes for students who have positive social attitudes if given learning by cooperative learning methods and conventional methods.

The main idea of this social interaction learning model is to collaborate in learning things that are academic in nature and some efforts to prepare students to become good citizens and form a social life that is as real as possible. This social interaction learning model is also based on the idea that collaboration is one of the most important phenomena in people's lives. This model group emphasizes the individual relationship with other people or society. This group centers on the process where reality is offered socially. As a consequence, the socially-oriented models mentioned above give priority to improve individual skills to connect with others, to act 
in democratic processes, and to work productively in society. Although this model group emphasizes social relations more than other aspects, the figures in this group also emphasize the development of academic study awareness.

The social interaction learning model emphasizes student learning activities in the presence of direct experiences received by students obtained from interaction and discussion. It aims to foster students in order to develop cognitive, affective and psychomotor aspects of students in a comprehensive manner and interact with their environment. This supports the theory put forward by Newcomb, et al (1985) explaining that social interactions occur through the processes of (1) communication, which is a form of interpersonal relationships where people can make contact with the contents of other people's thoughts, (2) norms, namely one's acceptance or a group of people against a rule, and (3) interpersonal response, namely the acceptance of a person or group of people who influence each other with the same way.

Social interaction learning model also emphasizes learning where students discover for themselves what they are learning, not just knowing from the teacher. By the learning social interaction, students also become more active and creative, considering learning will be more meaningful if cognitive, affective, and psychomotor functions can work together. With the interaction learning model, students learn directly by watching or observing the behaviors of the supporting learning material found around the students. Therefore, the teacher can plan learning activities inside and outside of the classroom.

\subsection{The Differences in Student Learning Outcome of Geographic Subject with Different Social Attitudes}

Based on the calculation of three-way anava as shown in Table 4.21, the source of variation B shows that the value of $F_{\text {count }}=13.26$, while the value of $F_{\text {table }}=3.86$ for $\mathrm{dk}(1.468)$ and the real level $=0.05$. Thus it can be concluded that there are differences in students learning outcomes of a geographic subject and different social attitudes namely high social attitudes $\left(\mathrm{B}_{1}\right)$ and low social attitudes $\left(\mathrm{B}_{2}\right)$. It is understandable that the success of learning is determined by various factors, including the factors associated with students, namely social attitudes. In this case, social attitudes are related to students' social attitudes which are manifested in words or deeds, agree or disagree, believe or not believe, obey orders or fight, frankly, brave, hate, and so on.

Aunurrahman (2011) explains that in learning activities, students' attitudes especially when starting learning activities are an important part to note because the subsequent learning activities are largely determined by the attitude of students when they will begin learning activities. When starting a learning activity students have an accepting attitude or emotional state to learn, then these students will tend to try to be involved in learning activities well, but if the more dominant is the attitude of refusing before learning or when going to start the lesson, then the students will tend to pay less attention or participating in learning activities.

Likewise, in taking Geography course, students have different social attitudes, for example, social attitudes between one student will be different from the other students'. Students with higher social attitudes will find it easier to process information and adopt ideas and thoughts that are in their minds compared to the students with lower social attitudes, especially if the learning model applied is a social interaction. Students with higher social attitudes will find it easier to process information and adopt ideas and thoughts that are in their minds compared to the students with lower social attitudes, especially if the learning model applied is a social interaction.

When students with high social attitudes are given learning that has the character of social interaction, the potential they have will be realized. This pleasant condition allows students to develop abilities in learning which are then expected to affect their learning outcomes. This is in line with the explanation of Sobur (2003) stating that social attitudes are closely related to someone's consideration to other individuals outside themselves.

This is in line with the explanation of Sobur (2003) stating that social attitudes are closely related to someone's consideration to other individuals outside themselves. The opposite will occur differently for students with low social attitudes who will experience difficulties in terms of studying Geography material taught by social interaction learning models.

The findings of this study are in line with the findings of previous studies conducted by Naijan (2014) that there are significant differences in historical learning outcomes for students who have a negative social attitude if given learning with different learning methods. Furthermore, the research conducted by Virani, Riastini, and Suarjana (2016) found students' social attitudes were good in aspects of honesty, discipline, responsibility, courtesy, and care. Although it is good, in the disciplinary aspect, $10 \%$ of students still do not wear a full and neat uniform, $32 \%$ of students arrive late and do not do assignments. Later on is the polite aspect, $12 \%$ of students still say rude. Furthermore, the aspect of confidence is still enough. This can be seen from the lack of courage that students come to the front of the class, are ashamed to express their opinions, and are ashamed to do 
assignments or questions on the board.

The research result conducted by Asmarawati, Riyadi, and Sujadi (2016) found that the process of integrating social attitudes carried out by teachers in preliminary activities can be providing modeling, assignments, directions, warnings, and prohibitions through examples of phenomena that exist in everyday life. The process of integrating social attitudes is carried out by the teacher in the core activities when students observe and the teacher, as well as students, discuss the questions on the Worksheet that students have worked in groups.

\subsection{The Differences in Students Learning Outcomes of Geographic Subject with Different Learning Motivations}

Based on the calculation of three-way anava as shown in Table 4.21, the source of variation $C$ shows that the value of $F_{\text {count }} 49.09$ while the value of $F_{\text {table }}=3.86$ for $\mathrm{dk}(1.468)$ and the real level $=0.05$. Dengan demikian dapat ditarik kesimpulan bahwa terdapat perbedaan hasil belajar Therefore, it can be concluded that there are differences in students learning outcomes of geographic subject with different learning motivation, namely high learning motivation (low learning motivation $\left(\mathrm{C}_{1}\right)$ and low learning motivation $\left(\mathrm{C}_{3}\right)$. This can be understood because learning motivation is one of the factors that play a role in encouraging students to carry out learning activities. As the driving force in a person to gain success in the learning process, students can be grouped into two, i.e. those who have low learning motivation and high learning motivation. Students highly motivated in learning will certainly look different when compared to those who are low motivated. This is in line with Djamarah's (2008) explanation that learning motivation functions as s a stimulant of action, motivation as a driver of action, and motivation as a director of action.

Likewise, in taking Geographic subject, students have different learning motivation between one student and another. Students with higher learning motivation will be more motivated to learn, process information or knowledge and find This is in line with the explanation of Uno (2007) that learning motivation has an important role in learning, namely: (1) determining things that can be used as reinforcement of learning, (2) clarifying learning objectives to be achieved, (3) determining the variety of controls for stimulation study, and (4) determining learning perseverance.

Students with higher learning motivation can learn attentively and try to get the best learning outcomes and usually will achieve learning outcomes according to their abilities. They always have a high spirit of learning and tend to want to find new knowledge. They also tend to be more confident in pursuing success in learning. Students who are highly motivated in learning can always complete tasks that are given easily, and if they find difficulties, they will ask questions and be optimistic that they can solve the problem well. Students who are highly motivated in learning can always complete tasks that are given easily, and if they find difficulties, they will ask questions and be optimistic that they can solve the problem well. For that reason, they are always satisfied with the results achieved because they are always in accordance with their intended goals.

Conversely, students who have low learning motivation do not give maximum attention to what they learn. They tend to be less eager to seek new knowledge. In general, they have low self-confidence because they are never sure of their abilities. Students who have low learning motivation will quickly give up if they find difficulties in learning, which in turn generates poor results obtained in learning. They are easily discouraged and passive so that their learning achievements lag behind other students.

Regarding this learning motivation, Siregar and Nara (2010) explain four ways that teachers can do in increasing student learning motivation, namely: (1) optimizing the application of learning principles, (2) optimizing the dynamic elements of learning, (3) optimizing the utilization of teachers' efforts in the learning and also become the factors that influence motivation, and (4) developing aspirations in learning. The findings of this study are in line with the previous research conducted by other researchers, i.e.

First, Hambali's (2004) study concluded that there were differences in learning outcomes of highly motivated subject groups and low motivated subject group in Physics subject learning outcome. High-motivated students have high learning outcomes, while low-motivated students have low learning outcomes. Second, Elisa's (2009) study concluded that there were differences in social studies learning outcomes between groups of students with high learning motivation and low learning motivation. Third, Siregar's (2010) study states that students who have high learning motivation will get higher learning outcomes than students with lower learning motivation. Fourth, Lestari's study (2013) found that there were differences in physics learning outcome between students who had high learning motivation and those who had low learning motivation with $\mathrm{F}=5.382$ with significance number of $0.023(\mathrm{p}<0.05)$.

\subsection{Interaction between Learning Models, Social Attitudes and Learning Motivation}

Based on the calculation of three-way anava as shown in Table 4.21, the source of ABC variation shows the 
value of Fcount $=16.02$ while the Ftable value $=3.02 \mathrm{for} \mathrm{dk}(2.468)$ and the real level $=0.05$. Hence, it can be concluded that there is an interaction between the learning model (A), social attitudes (B) and learning motivation (C). Obtaining optimal learning outcomes requires a more meaningful learning model where through this model, the students are able to construct their own knowledge and skills needed, not because they are told by the teacher alone but students are able to construct their own knowledge in their minds. For this reason, the teacher's knowledge and understanding of the learning model in implementing learning are very important as an effort to optimize learning. Teachers are required to be able to improve the quality of learning and must pay attention to nature, know the objectives of the subjects being taught, and consider the characteristics of students between social attitudes and learning basically, the learning model applied by the teacher can provide clear direction and facilitate students to achieve learning goals. Social interaction learning model encourages students to gain broad opportunities to develop their potential of social attitudes, in addition, to encourage students to understand themselves, the social dynamics that occur following social devices happened directly and real so that this matter will be hopefully brought influence for the positive learning outcomes.

In addition, it can be understood that the application of the learning model by the teacher will not achieve maximum results if there is no motivation for students to learn. Therefore, learning motivation factors need to get teacher's in carrying out education, in this case, the teacher should be able to encourage students to be motivated to learn through various efforts made. Thus it can be understood that the interaction between learning conditioning designed by the teacher through the application of learning models and the formation of student's social attitudes and learning motivation is a unity that cannot be separated in carrying out learning so that students are expected to obtain maximum learning outcomes.

These research results are in line with the study conducted by previous researchers including the results of Nur Laila, Hariyono, Sumarmi's (2016) findings showing an increase in student motivation in the first cycle, the percentage reached $77 \%$ with "High" criteria and in cycle II with the percentage reached $96 \%$ with "Very High" criteria. There is an increase percentage of $19 \%$. Therefore, the Group Investigation learning model is proven to be able to increase student learning motivation in social studies of class VIII H SMP 01 Batu.

Furthermore, the results of Kusumaningrum's (2012) research showed that student's motivation and learning outcomes of the sociology subject after the implementation of the learning model especially the cooperative learning model in the developmental material of social groups and multicultural communities had increased. These results can be seen from the average of learning motivation and evaluation of student learning outcomes of sociology subject at class XI of Social 4, SMAN Colomadu Karanganyar which has increased. Student learning motivation has increased by $10.6 \%$ from the first cycle of $68.79 \%$ to $79.39 \%$ in the second cycle. Thus the students learning motivation of class XI of social 4 at SMAN 1 Colomadu Karanganyar which was originally classified as moderate, after the action became very high.

\subsection{Interaction between Learning Models and Social Attitudes}

Based on the calculation of three-way anava as shown in Table 4.21, AB variation source AB shows the value of $F_{\text {count }}=4.42$ while the value of $F_{\text {table }}=3.02$ for $\mathrm{dk}(2,468)$ and the real level $=0.05$. Thus it can be concluded that there is an interaction between the learning model (A) and social attitudes (B). Teacher's knowledge and understanding of the learning model in implementing learning is very important as an effort to optimize learning. Teachers are required to be able to improve the quality of learning and must pay attention to nature, know the objectives of the subjects being taught, and consider the characteristics of the students, in this case, are the students' social attitudes.

There are many varieties of learning models, therefore a teacher must be able to determine which learning model is most appropriate and in accordance with the learning objectives, and the characteristics of students' social attitudes. One of the right learning models to shape students' social attitudes is social interaction learning models.

The social interaction learning model emphasizes on student learning activities in the presence of direct experiences got by students obtained from the student interaction with learning resources and other students in the form of high or positive students' social attitudes. Therefore, by the high school students' social attitudes towards the learning implementation and its impact on students in the future, of course, it is expected that the learning outcomes obtained by these students can also achieve maximum results. Thus it can be understood that there is an interaction between learning conditioning designed by the teacher through the application of learning models and social attitudes in obtaining maximum learning outcomes.

The results of this study are in line with the study carried out by Istikomah, Hendrato, and Bambang (2010) that one of the social interaction learning models is group investigation showing a higher percentage of scientific attitudes of group investigation learning models than Jigsaw learning model. It was concluded that the group 
investigation learning model more effectively fosters the scientific attitude of students. Therefore, it is recommended to use a group investigation learning model so that students' scientific attitudes can be grown.

\subsection{Interacion between Learning Models and Learning Motivation}

Based on the calculation of three-way anava as shown in Table 4.21, the source of AC variation shows the value of Fcount $=6.49$ while the value of Ftable $=3.02$ for $\mathrm{dk}(2,468)$ and the real level $=0.05$. Thus it can be The learning model implemented by the teacher in real learning activities is to facilitate students to acquire the knowledge, skills and attitudes expected to be mastered by the students. For that reason, the use of the right learning model and in accordance with the characteristics of students will provide good learning outcomes.

It is not easy for the teacher to be able to generate student learning motivation in learning teaching material, in this case, is Geography teaching material. The teacher must be able to apply the appropriate learning model for students who have different learning motivation characteristics. The lack of teachers' ability to design and implement learning models that are in accordance with the characteristics of students' learning motivation will result in difficulties for students to digest the material provided. In addition, it will also cause boredom in the learning process. This social interaction learning model is a learning model that seeks to arouse students' curiosity towards subject matter through interactions that students make with learning resources and student and other student interactions. For that matter, students with higher learning motivation are more dominant in interacting with learning resources and other students than students with lower learning motivation.

Students with higher learning motivation will enable them to explore new knowledge by interacting with learning resources and they can concentrate and play an active role in learning activities. Students who are highly motivated will feel happy because they are challenged to get new knowledge in learning, and this enables them to improve their learning outcomes. While students with lower learning motivation are having less interaction with learning resources and other students in discovering new knowledge. Low motivated students do not want challenging activities; they are more interested in getting new knowledge from the teacher, not by finding themselves in other words the students tend to be passive. Thus it can be understood that there is an interaction between learning conditioning designed by the teacher through the application of learning models and learning motivation in obtaining maximum learning outcomes.

The findings of this study are in line with the results of the previous studies conducted by Lestari (2013) which investigated that there was an interactive influence between learning models and learning motivation on Physics learning achievement with a value of $\mathrm{F}=12.206$ with a significance level of $0.001(\mathrm{p}<0.05)$. Likewise, the results of the research by Hendrayana, Thaib and Rosnenty (2014) about student learning motivation showed that the average level of learning motivation was categorized in very high criteria with a percentage of $55.3 \%$ and $44.7 \%$ of learning motivation was categorized in high criteria, in this case, there are many factors that influence the contribution to the achievement of students' average scores, one of them is learning motivation. Learning motivation is very important in the learning process because the learning process requires interaction and active participation from students to succeed. The results of Fauzi, Dwiastuti and Harlita's (2011) research indicates that the value of students' learning motivation in biology subject (pre-cycle) before being given the action in the form of the application of learning models especially the cooperative learning model is still low. Student learning motivation value of biology subject has increased gradually after the implementation of actions in cycles I and II.

\subsection{Interaction between Social Attitudes and Learning Motivation}

Based on the calculation of three-way anava as shown in Table 4.21, the source of $\mathrm{BC}$ variation shows the value of $F_{\text {count }}$ by 4.11 while the value of $F_{\text {table }}=3.86$ for $\mathrm{dk}(1.468)$ and the real level of 0.05 . Thus it can be concluded that there is an interaction between social attitudes (B) and learning motivation (C). Each student basically has different characteristics of social attitudes and learning motivation so that the different characteristics result in the acquisition of different learning outcomes. According to Sardiman (2003), learning motivation can be said to be the overall driving force in students that raises learning activities, and gives direction to learning activities so that the desired goals can be achieved.

Students with high social skills and learning motivation will make it easy for them to express what is in their minds, express their desires and opinions through the words delivered both by speaking, reading and writing. Conversely, students with low social attitudes and low learning motivation will find it difficult to express what is in their minds, express their desires and express their opinions through words conveyed both by speaking, reading and writing. The results of previous studies related to the results of this study conducted that based on the results of research conducted in three cycles, the application of learning in this case the use of modules can increase learning motivation and learning outcomes can achieve $85 \%$ clarity of total students, namely the value of knowledge and practicum $88.24 \%$ and attitudinal value of $91.18 \%$. 
Thus it can be understood that in the learning process, social attitude and student learning motivation can develop if the teacher always gives an opportunity to students to express their ideas and opinions and motivate them to learn. Students are also encouraged to always have the courage to convey something, which is in their mind so that students can develop their social sensitivity. Hence it turns out that the classroom environment which always provides opportunities for students to deliver something both orally and in writing can improve their social attitudes and learning motivation. For that matter, it can be understood that there is an interaction between social attitudes and learning motivation in obtaining maximum learning outcomes.

\subsection{Implication}

In implementing Geography learning, a teacher can apply other learning models outside the social interaction learning model. Consequently, to make students succeed in learning, the teacher should pay attention to the students' social attitudes, if the learning model is less appropriate in learning; it will certainly result in reduced student active participation in learning. Consequently, to make students succeed in learning, the teacher should generate student learning motivation by motivating the involvement and active participation of students in learning and creating a more interactive and effective learning atmosphere in achieving learning goals. The consequence to make students succeed in learning is the teacher should apply a planned learning model and of course pay attention to the characteristics of students, create a conducive learning environment for learning and condition students in learning groups that interact with each other in order to achieve maximum learning outcomes.

\section{Conclusion and Suggestion}

Based on the research result, data analysis and the discussion of the research results can be drawn from the findings that there are no differences in student learning outcomes of Geography subject taught with social inquiry learning models $\left(\mathrm{A}_{1}\right)$, social simulation learning models $\left(\mathrm{A}_{2}\right)$ and group investigative learning models $\left(\mathrm{A}_{3}\right)$. There are differences in the learning outcome of geography subject and different social attitude, which is a high social attitude $\left(B_{1}\right)$ and social attitude $\left(B_{2}\right)$. There is an interaction between the learning model $(A)$, social attitudes (B) and learning motivation (C). There is an interaction between learning models (A) and social attitudes (B). There is an interaction between learning model (A) and learning motivation (C). There is an interaction between learning model (A) and learning motivation (C).

Suggestions that can be given are teachers should use other learning models except for social interaction learning models, show faces that are always friendly and not easily angry, sometimes they joke with the child amid the teaching material explanation, besides they have to avoids rude words and try to create a relaxed and tense classroom atmosphere, this can be seen by their behavior sometimes interspersed teaching activities with humor, they consider differences in social attitudes by giving stimuli to students both at the beginning of learning and reflections at the end of learning so that social attitudes are formed well.

\section{References}

Ahmadi, A. (2007). Psikologi Sosial. Jakarta: Rineka Cipta.

Arend, R. (2008). Learning to Teach. Belajar Untuk Mengajar. Yogyakarta: Pustaka Pelajar.

Asmarawati, E., Riyadi, \& Sujadi, I. (2016). Proses Intergrasi Sikap Sosial Dan Spiritual Dalam Pembelajaran Matematika Pada Siswa Kelas VII SMP Negeri Di Kecamatan Purwodadi. Jurnal Elektronik Pembelajaran Matematika, Vol.4, No.1, hal 58-69 Maret 2016. Universitas Negeri Semarang.

Aunurrahman. (2011). Belajar dan Pembelajaran. Bandung: Alfabeta.

Djamarah, S. B. (2008). Psikologi Belajar. Jakarta: Rineka Cipta.

Elisa. (2009). Pengaruh Model Pembelajaran dan Motivasi Belajar Terhadap Hasil Belajar IPS. Tesis. Medan: PPs Unimed.

Fauzi, R., Dwiastuti, S., \& Harlita. (2011). Penerapan Metode Pembelajaran Untuk Meningkatkan Motivasi Belajar Biologi Siswa Kelas VIII SMP Negeri 14 Surakarta Tahun Pelajaran 2011/2012. Jurnal Pendidikan Biologi, 3(3).

Hambali. (2004). Pengaruh Strategi Pembelajaran dan Motivasi Berprestasi Terhadap Hasil Belajar Fisika. Tesis. Medan: PPsUnimed.

Highet, G. (1955). The Art of Teaching. New York: Mc. Graw Hill Book Company.

Istikomah, H., Hendratto, S., \& Bambang, S. (2010). Penggunaan Model Pembelajaran Group Investigation Untuk Menumbuhkan Sikap Ilmiah Siswa. Jurnal Pendidikan Fisika Indonesia 6. 2010. 40-43 Universitas 
Negeri Semarang.

Joyce, B., \& Weil, M. (1992). Models of Teaching. USA: Allyn and Bacon.

Kusumaningrum, T. N. (2012). Penerapan Pembelajaran Kooperatif Tipe Student Teams Achievement Division (Stad) Untuk Meningkatkan Motivasi Dan Hasil Belajar Sosiologi Pada Siswa Kelas Xl Ips 4 Sma Negeri Colomadu Karanganyar Tahun Pelajaran 2011/2012. Sosialitas, 2(1). https://doi.org/10.23887/jippg.v1i2.16399

Laila, N., Hariyono, \& Sumarmi. (2016). Meningkatkan Motivasi Belajar Siswa Pada Pembelajaran IPS Menggunakan Model Pembelajaran Kooperatif Tipe Group Investigation. Jurnal Teori dan Praksis Pembelajaran IPS Universitas Negeri Malang. https://doi.org/10.17977/um022v1i22016p123

Lestari, N., \& Nyoman, S. (2013). Pengaruh Model Pembelajaran Berbasis Masalah Dan Motivasi Belajar Terhadap Prestasi Belajar Fisika Bagi Siswa Kelas VII SMP. e-Journal PGSD Universitas Pendidikan Ganesha Jurusan PGSD.

Naijan. (2014). Pengaruh Metode Pembelajaran Dan Sikap Sosial terhadap Hasil Belajar Sejarah Siswa SMAN 12 Tanggerang Selatan. Jurnal Pendidikan Sejarah, 3(1). https://doi.org/10.21009/JPS.031.03

Newcomb, H., \& Hirsh, P. (1985). Television as a cultural form. Mass communication review yearbook, 5, 275.

Sardiman, A. M. (2003). Interaksi dan Motivasi Belajar Mengajar. Jakarta: Rajagrafindo Persada.

Seels, B., \& Glasgow, Z. (1998). Making Instructional Design Decisions. New Jersey: Prentice Hall.

Seels, B., \& Richey, R. C. (1994). Instructional Technology; The Definition And Domains of The Field. Washington: AECT. Alihbahasa: Dewi S. Prawiradilaga, Raphael Rahardji dan Yusufhadi Miarso. Jakarta: Universitas Negeri Jakarta.

Siregar, E., \& Nara, H. (2010). Teori Belajar Dan Pembelajaran. Bogor: Ghalia Indonesia.

Siregar, R. (2010). Pengaruh Strategi Pembelajaran dan Motivasi Belajar Terhadap Hasil Belajar Matematika. Tesis. Medan.

Sobur, A. (2009). Psikologi Umum. Bandung: Pustaka Setia.

Sugiyono. (2010). Metode Penelitian Pendidikan. Bandung: Alfabeta.

Uno, H. B. (2007). Teori Motivasi dan Pengukurannya, Analisis Di Bidang Pendidikan. Jakarta: Bumi Aksara.

Virani, I., Ayu, D., Riastini, I., Putu, N., \& Suarjana, I. M. (2016). Deskripsi Sikap Sosial Pada Siswa Kelas IV SD Negeri 4 Penarukan Kecamatan Buleleng Kabupaten Buleleng. Vol: 4 No: 1 Tahun.

Wertheimer, M. (1912). Experimentelle Studien über das Sehen von Bewegung. Zeitschrift für Psychologie, 61, 161-265. Translated as "Experimental studies on seeing motion". In L. Spillmann (Ed.), (2012). On motion and figure-ground organization (pp. 1-91). Cambridge, MA: M.I.T. Press.

\section{Copyrights}

Copyright for this article is retained by the author(s), with first publication rights granted to the journal.

This is an open-access article distributed under the terms and conditions of the Creative Commons Attribution license (http://creativecommons.org/licenses/by/4.0/). 